\title{
TYPE 2 DIABETES IN PEOPLE FROM CULTURALLY AND LINGUISTICALLY DIVERSE BACKGROUNDS: PERSPECTIVES FOR TRAINING AND PRACTICE FROM NUTRITIONAL THERAPY AND DIETICIAN PROFESSIONS
}

\author{
Lily Stojanovska ${ }^{1, *}$, Bhensri Naemiratch ${ }^{1,2, \#}$, Vasso Apostolopoulos ${ }^{1, *, \#}$ \\ ${ }^{1}$ Centre for Chronic Disease, College of Health and Biomedicine, PO Box 14428, Melbourne VIC 8001 Australia \\ ${ }^{2}$ Current address, Darebin City Council, Gower Street, Preston, VIC, Australia \\ *Corresponding Authors: Lily Stojanovska and Vasso Apostolopoulos; Centre for Chronic Disease, College of \\ Health and Biomedicine, Victoria University, VIC Australia. Tel: +613 99192737 ; Fax: +613 99194565 \\ Email: 1ily.stojanovska@vu.edu.au and vasso.apostolopoulos@vu.edu.au
}

Emails of all authors: Lily.Stojanovska@vu.edu.au; Vasso.Apostolopoulos@vu.edu.au, Bhensri.Naemiratch@darebin.vic.gov.au

\# These authors contributed equally

\begin{abstract}
Objective: To explore the perspectives of nutritional therapy and dietician practitioners, undergraduate students and academics working with people with type 2 diabetes and who are from culturally and linguistically diverse (CALD) backgrounds. Methods: A qualitative study design of in-depth semi-structured one-on-one interviews with a total of 24 participants ( 8 practitioners, 8 students and 8 academics) in the fields of nutritional therapy and dietetics. Open-ended questions focused on the perspectives and experiences (learning, practice and teaching) of working with people of CALD backgrounds who have type 2 diabetes. All interviews were recorded for thematic and textual analysis. Results: Inter-related themes which were confirmed with investigator triangulation were the understanding of (i) the concepts of culture and diversity, (ii) the concepts and influences of health, diabetes and food across cultures, (iii) influences within and across cultures and (iv) systems and resourcing. Overarching perspectives across these themes suggested frustration in having sufficient capacity to assess comprehensively, to deliver effective, comprehensive and high quality management plans, and to achieve required health behavioural changes with people from different CALD backgrounds. Conclusions: There's a need for improvements in the undergraduate education and training and in professional development programs; training and resourcing of interpreters in delivery of health-related information and working with health professionals; for focus on culturally appropriate management plans that involve consultation with key decision makers in families and communities; and, reviews of the systems for supporting and resourcing nutritional therapists and dieticians in professional development from undergraduate to practice levels.
\end{abstract}

Keywords: Diabetes service, Culturally and linguistically diverse, CALD, dieticians, nutritional therapy.

\section{INTRODUCTION}

Australia is experiencing high rates and costly complications of type 2 diabetes amongst numerous countries worldwide. With a population of just over 20 million, 1.7 million had type 2 diabetes of those that were registered in 2005. It is estimated that by 2031 it will have doubled to 3.3 million [1].
In Australia, accredited 'Nutritionists' and 'Dieticians' are recognized for practice through one or more members of the Federation of Nutrition Organisations, such as Food Standards Australia and New Zealand, the Nutrition Society of Australia, or the Dieticians Association of Australia [2]. The distinctions between a nutritionist and a dietician lies in the number of years to qualify, being around 3 years for 
nutritionists and 4-5 years for dieticians, hence, their roles and responsibilities are different. Nutritionists help people achieve their health goals by providing information and advice regarding health and food choices. They also have expertise in public health nutrition and community health [3]. Dieticians however, are qualified to work in private clinical practice, hospitals and in medical nutrition industries. A dietician can prescribe a dietary treatment to people who have medical and physical conditions, such as, food allergies, cancers, overweight, type 2 diabetes. A dietician can also work in public health and community health [3]. In both professions, for type 2 diabetes for example, the key role is to optimize food and nutritional intake for health, often also to achieve weight loss, behavioural change and to work as a contributor / collaborator to a multidisciplinary health service team [4].

There is little empirical research to guide health care professionals regarding the most appropriate approach for working with people of culturally and linguistically diverse (CALD) backgrounds, with type 2 diabetes [5]. There is also little to guide undergraduate teaching, ongoing professional development, policy and resourcing to ensure depth, quality and effectiveness [6]. The purpose of this study was to gather information by interviewing upcoming and existing members of the fields of dietetics and nutritional therapy in an effort to identify descriptive categories that could be used to inform practice and the associated education, policy and resourcing systems.

\section{MATERIALS AND METHODS}

\section{Design}

The qualitative approach adopted for this study was based on 'interpretative structures, emotionality and power relations that permeate' the health professional and client meetings [7]. Knowledge capture was of interpretations from practitioners, academics, and students in the nutritional therapy and dietetics professions of their interactions in working with CALD background clients who have type 2 diabetes.

\section{Study Setting}

Semi-structured in-depth interviews were conducted. An interview guide was used to prompt discussion regarding the cultural diversity and the perceptions/experiences of each interviewee in working with migrant and refugee clients; and to explore strategies for change. This guide was developed by the research team, experienced in mixed methods, which comprised a biomedical scientist, a public and allied health specialist and researcher, and a student of nutritional therapy. Interviews were undertaken by a consultant with expertise in qualitative research, in working with multicultural communities and in anthropology. No payment was provided for participation; the interviewer travelling to the site was nominated by each participant.

A total of 24 in-depth interviews of durations ranging from 1-3 hours were conducted. These were with 16 professionals who each had recognized qualifications in the fields of nutritional therapy or dietetics and who each had been practicing as a health professional $(\mathrm{n}=8)$ or teaching and researching at a University $(n=8)$ for at least 3 years. Eight students who were enrolled in undergraduate courses from Universities across Melbourne were also interviewed.

\section{Participants}

Participants were recruited using a non-probabilistic maximum variation sampling strategy so that the collected data would show sufficient variation of perception and experience. A general information pack about the study was forwarded to public and private health service organizations that employed nutritional therapists and dieticians, to individual professionals who worked in these fields, and to the academic departments of universities around Melbourne which provide undergraduate education and training and employ academics and researchers in these disciplines. Those interested in participating in the study contacted the research team directly, and were provided with more detailed information sheets about the research prior to signing the consent to participate. All participants gave informed consent to participate in this study, which was approved by the Human Research Ethics Committee of Victoria University, Australia.

\section{Data Collection}

Questions were asked sequentially in 3 sections, each with agreed upon questions, statements and probes to elicit information. With exhaustion of responses to each section, the interviewer moved the discussion to the next section. The number of interviewees in each category (practitioner, $\mathrm{n}=8$; academic, $n=8$; student, $n=8$ ) was sufficient to gain confidence that no new themes were emerging. The first section was introductory and to explore experiences and perspectives on the topic of 'cultural diversity'. The second section allowed for an in-depth account of what transpires in meetings between a health professional and the client of CALD background with diabetes. The third section was to foster ideas and innovation for practice, resourcing and systems. 


\section{Analytical Procedure}

Interviews were recorded with the consent of the participant. Each recording was transcribed verbatim and entered for qualitative analysis in the workspace of the NVivo 9 program (CQSR International Pty Ltd). Cluster analysis was performed to analyse word similarity across transcriptions, and Pearson correlation coefficients were determined for each pair of transcriptions. One researcher (KB) first coded the data according to content analysis to gain 168 codes parsed into 1073 coding references. Through a reiterative process involving group consensus and a focus on straight subjective description, codes were grouped into themes with sub-themes. The derivation of themes was considered complete when all members of the research team concurred that the generated collection of themes captured all of the participants' responses to the interview questions. The descriptive-qualitative approach enabled the researchers to "stay close" to the data and understand the subjective experiences of the participants; this is considered the method of choice when a straight description of the data is desired.

\section{RESULTS}

Suggestive of both theme saturation and a suitable sampling technique, cluster analysis revealed a moderate to high degree of word similarity across the 24 transcripts, with Pearson correlation coefficients between transcript pairs ranging from 0.61-0.97. The results are presented as a summary of the main themes identified in the analysis of the data, accompanied by representative quotations from the participants (practitioner, $\mathrm{n}=8$; academic, $\mathrm{n}=8$; student, $\mathrm{n}=8$ ). Data analysis provided rich descriptions across different themes suggesting frustration in having sufficient capacity to assess comprehensively, to deliver effective, comprehensive and high quality management plans, and to achieve required health behavioural changes with people from different CALD backgrounds. From the analysis it was evident that there were inter-related themes with investigator triangulation, however, 3 primary theme outcomes were evident.

\section{Understanding the concepts of culture and diversity by health professionals}

Culture and diversity is the quality and variety of different cultures, as opposed to a homogenous culture. It is important to understand the conceptualizations of culture and diversity amongst different individuals. We analysed this by comparing the understandings of health professionals, academics and students. It was apparent that across the professions there was great variation in their interpretation of culture and diversity. A group of respondents perspective on cultural diversity was based on language and food:

Practitioner 5: By culture I mean people's language, food ideas, eating patterns, food rituals and beliefs

Student 3: It's not just about cultural diversity but about diversity, right, because we have religious, political, philosophical and linguistic diversity

Student 4: It is about nutrition and it is about cultures too

Student 6: About the different cultures and what they eat I guess...

Student 7: It is people from all different cultures all coming together..

Interestingly, for some respondents, the definition of culture and diversity was related to the individual and experiential level:

Academic 4: It [culture and diversity] is not something that I can define and say that is it. It is broad and it has so many meanings for so many people that it is not something that I feel comfortable defining I guess...

Student 1: I understand cultural diverse when people from different countries. Um, it is hard, difficult and people not understand you...

With the gathering experience of working with people of different cultural backgrounds, came acknowledgement of not knowing what is not known and the difficulties of influencing clinical practice positively with this knowledge:

Academic 4: I think my definition of culture has become more confused over the years...

Student 5: I guess cultural diversity for me was very complicated and brought out more problems than solutions for the patients.

The changing acknowledgement of culture and diversity for practice was noted:

Academic 2: Like all new and 'in' concepts, ideas and philosophies everyone is doing it, thinking it, practicing it and engaging in it. My concerns are that a lot of people are paying lip service to it. Academic 4: What is culturally right today may change tomorrow...

Even though some respondents, in particular academics, indicated an interest in learning more about cultural diversity and the need for health professions to do so, others, in particular students, were 
less interested in advancing the learning of culture and diversity for practice:

Academic 1: We often see people from different cultures and we have very little understanding about who they are; what they think and feel about our ideas around nutrition, cooking practices and health.

Academic 6: I do love cultural diversity. It keeps us all on our toes. It is vibrant and emotionally charged. The cultures have changed and will continue to change and we have really no idea of what, how and in what way we should be working with them...

Student 4: Like if they come into our country isn't it about our rules? Isn't it about what we know? So why do we not just tell them, look this is how it is?

Student 6: And I think that when I go into private practice I am going to be seeing Anglo Saxons mainly.

and perhaps not as cognisant, as the following respondent, of the risks of not learning:

Academic 4: I know that I have to be so careful and aware of the different cultural nuances

\section{Concepts and influences of health, diabetes and food across cultures}

Metabolic syndrome (diabetes, cardiovascular disease, cholesterol) is caused by a combination of lifestyle (physical inactivity, lack of sleep, diet, stress, obesity), immunological complexity and genetic factors [8-10]. An understanding of the link between food and diabetes and overall different food groups and its effects on health, varies amongst different cultures and varies according to their educational status. Respondents did not have a clear understanding regarding the different ways in which health, ill-health and their relationship to food was understood by clients from CALD backgrounds:

Academic 4: I think that it is also interesting that people have different ideas about what health is. Academic 3: Well yeah I have even thought that, what do people think about illness? health? healthy eating?.

One particular responded explored this understanding, to reveal broadness in the concept of health and its relationship to ill-health, and based this on what they were involved or influenced by in the past: Academic 4: We ran some focus groups with the women and they said that healthy is just having a happy family really.... and, some women said I am healthy when I take my blood pressure tab- let and my blood pressure doesn't go up.... and I'am healthy when I can get up in the morning and I can still take 10 tablets not 20 like others in this group.....

because of having starved and survived refugee camps and having long periods of not having food, a chubby child or person is a healthy person or child.

The incidence of type- 2 diabetes has increased exponentially in the last 50 years, which is in parallel to obesity and inadequate diet. In 198530 million were registered as being diabetic, compared to 285 million in 2010 and 350 million today worldwide. It is recognized as a global epidemic by the World Health Organization [11]. Interestingly, respondents commented on the increasing rates of type 2 diabetes however, this exponential prevalence was viewed differently amongst various communities, ranging from denial to normalization of the condition:

Practitioner 3: They don't like to hear about diabetes because in some cases diabetes is too far removed from their everyday reality. It is what happens but not what you live day in day out.

Student 5: My dad is a diabetic and so is my mother but I have never seen them change their diet or stop drinking so if it was serious they would probably do that. We never speak about it so I assume that it isn't a problem for them. I guess it might sound weird to you but it is normal in my family...

Furthermore, there are major misconceptions and mistaken beliefs relating to what diabetes is and how one should deal with it.

Practitioner 2: Aside from all these factors we have the issues about illness constructions, beliefs, values and misconceptions.

Practitioner 5: I think she did believe that one 'catches diabetes.

Academic 5: They believe that diabetes is caused by sugar ... that in Australia, food is not healthy ... it is injected with hormones that cause so many problems with their health ... that stress levels and family disharmony really cause ... illnesses like diabetes ... if they stop worrying then everything will be okay ... if they could just get their family issues under control then everything will settle with their sugar.

Practitioner 1: I noted that there were language, cultural and health barriers in the hospital. When I say health barriers I mean health beliefs ... For me this is the lived experience of culture; culture's impact on health and illness. 
Diabetes is a complex condition, which can affect the entire body [12]. Understanding of what diabetes is, is important, however, patients tend to place insufficient importance on diabetes and on its management:

Academic 5: Diabetes is a funny condition ... it is a condition that is ... not seen as important. They can't really see an effect or feel pain therefore it is not a condition that they need to worry about ... they tend to disregard information about diabetes and the various warnings.

Many people have a general idea of what diabetes is, but misconceptions about the causes may lead to negative health and management outcomes. In fact these misconceptions have negative impacts on the uptake by the patient of advice. It is interesting that such beliefs exist, and is considered as fate, a curse, a result from past sins, etc.:

Practitioner 6: There's a lot of fatalism that is out of their hands, what's the point in doing that, it's about a curse they put on them in the village...

Academic 6: Someone at church gave me 'mati' (evil eye). I got diabetes because I've been bad.

Practitioner 1: Bad spirits cause disease, medications may not be able to cure you of the bad spirits.

Academic 6: Fruit increases blood sugar, so they don't eat fruit and when you try to explain that it is not all fruit they don't want to hear it. They have this resistance to taking insulin. They believe that insulin means or equals death...

\section{Understandings and influences within and across cultures}

The next theme that was extracted from the analysis was participants' perceptions of food and cooking amongst migrant patients with type 2 diabetes. It was the general understanding amongst academics, practitioners and students that certain food practices and cooking methods were unhealthy. Their understanding was that as perceptions of food amongst certain migrant groups were not the same as it is in the western society, this would as a result make it a challenging task to educate them about new and healthier food and cooking methods in the country of settlement. One participant reported,

Student 1: Unfamiliarity with our food or unfamiliarity with our cooking practices here that they don't have that concept of what is healthy eating. A lot of the African refugees don't have... they don't have that concept of what is healthy eating? They don't link...food to health like we do.
This lack of understanding and familiarity of what constitutes "healthy" food and cooking practices that exist in the host society coupled with unhealthy misconceptions of weight and body image can be perceived as a dangerous combination for the management of diabetes. This was evident by,

Student 2: Being overweight is considered healthy.

Oh and oh my God, I have seen some of them put so much salt on their food that I nearly died.

Moreover some academics clearly pointed out the importance of adopting their cultural cooking methods and foods into healthy diets.

Academics: How can you integrate foods that are culturally relevant to you into a healthy diet here and I think that is what one of the things that you have the best health outcomes when you can integrate some of their...um... yeah, their cultural diet into a well-balanced Australian diet.

Even though this suggestion about the adaptation of ethnic cooking methods according to a more healthier version of Australian cooking methods is put forward with a well-meaning intention it could lead to assumptions that could negatively impact the relationship between the health care professional and the CALD client. However it was evident that there were also health professionals and academics that appeared to have a more impartial view about cultural and ethnic cooking methods and food consumption patterns of CALD communities. As one pointed out,

The concept of food, as part of the social and religious fabric, is not just about body nourishment. A focus on the world of food and culture is needed in your areas of work.

This quotation however, implies that there is a negative perception amongst some participants in that all ethnic cooking methods and diets were unhealthy and should be adapted to the Australian way, if the diabetic CALD patients want to lead a healthy lifestyle. This lack of understanding would lead to wrong perceptions of cultural / ethnic ways of cooking and therefore, would even lead to a larger gap between the health professional and the CALD client. This signifies either the need to train more health professionals from CALD background or the need to provide more cultural knowledge to students of health disciplines. The lack of knowledge about ethnic food and cooking methods and food practices could lead to dangerous assumptions of ethnic cooking and food practices that would result in widening the gap of communication between the CALD client and the health professional which could consequent- 
ly result in the ineffective diabetes education among CALD groups.

Furthermore, the recognition of the importance of gender roles in different cultures is essential when recommending diet regimes to patients with diabetes. The theme of capacity of clients to implement dietary and other lifestyle changes in their homes and communities and the impact of gender roles in some cultures on this capacity was mentioned particularly by many practitioners but also by one academic. In some cultures, for example, the gender roles of 'women doing the cooking', and 'men doing the decision making and talking' are very defined; in others, these roles are less distinct.

Practitioner 7: I ask about gender roles within that culture. For example, what are the roles of a man and the roles of a women and who takes charge of a person's health. How gender roles may impact on that may need to be made.

Practitioner 3: A situation arose when a gentleman didn't like his wife's cooking so therefore he ate 8 bananas instead of the meal his wife had made. He said it is not his place to question his wife's cooking.

Another participant spoke of a situation where she was regarded as insufficiently qualified to give advice or treat a male client who preferred to see a male practitioner. Dependence of females on the males to attend consultation sessions was also identified.

Women of certain cultures don't drive and may not have access to facilities, appointments and education forums. Some women rely heavily on their husbands for lifts to their appointments and the men may not be interested or see a need for the woman to go to their appointment ... There are also issues using public transport in some cultures, for all sorts of reasons.

Interestingly, some participants also expressed their concern over how certain types of body image among males and females could have an impact on the onset of diabetes.

Dietician 6: South African women believed that it was good to be overweight because that was an indication that you had money and were not hungry. This was very important for each person's self-esteem and for the community.

Moreover, the theme that was identified by the researchers, was the hardships that the health professionals went through when working with interpret- ers. Some interviewees spoke about the importance of working with interpreters, but mentioned also such challenges as much more appeared to be translated by the interpreter than was asked by the practitioner; or translations that did not appear to reflect exactly what was being stated by the practitioner.

Practitioner 6: I will try and have a professional consultation but the interpreter can actually sabotage that and make the whole consultation very unprofessional; having a conversation when I am trying to explain something, interrupting me while I am talking, giving advice.

Academic 4: You need to be aware and check that the translation is correct, that the translators understand the cultural nuances of that and that is within the context of what the client was saying and not taken out of context.

To elaborate on the quote given by Academic 4 , points out the notion of cultural nuances and differences and nuances of languages that have been commented on in the final report of the Survey of Asian people and health professionals in the North and West Auckland, 2001 could be brought into light. For example the report that the Asian Health Support Service produced states that an advice such as "you have to take this medicine until finished" could be very well misunderstood by the Asian patient. He/ she could understand it as that he/she has to take the medicine until he/she dies (Survey of Asian people and health professionals in the North and West Auckland) [13].

For example, I will try and have a professional consultation but the interpreter can actually sabotage that and make the whole consultation very unprofessional; having conversations when I am trying to explain something; interrupting me while I am talking; giving advice; looking at people's food chart and then proceeding to point to particular foods as if they are running the consultation.

The above quotation from a dietician's interview shows that clearly there was no collaboration between the health professional and the interpreter. It also demonstrates that there is a lack of mutual understanding between the 2 parties. This clearly points out the importance of prior establishment of a professional relationship between the health professional and the interpreter to the actual clinical presentation of the client.

The most common theme that was identified was related to the education, particularly at undergraduate level being the limited learning of cultural diversity offered at tertiary education levels. The processes 
of dealing with and taking cultural elements into account of CALD patients were not theoretically taught to undergraduate and postgraduate students in their training. Many participants pointed out the lack of education they received at tertiary education regarding communicating and dealing with patients from CALD backgrounds.

Under the 'theme' of not having learnt enough regarding issues dealing with cultural diversity at the tertiary level or during training, the majority of the participants (18/24) spoke about the minimal amount of cultural diversity learning during their university degree and the need to place greater emphasis on cultural issues within the university's education system.

Academic 1: I don't think the curriculum teaches a lot about cultural diversity.

Practitioner 3: I can't remember having learnt a lot about cultural diversity. In fact it was extremely limited. My experience of cultural diversity happened outside of my course, from friends. I learnt about cultural diversity when I did my work experience.

Many participants believed that education of cultural diversity could not be delivered theoretically in classes.

I would have to say that I don't think one can be taught theoretically about cultural diversity. I think that the only way to learn is to practice.

Rather it should include aspects related to:

- all cultures, not just the cultures that are 'in vogue' at the time

- diversity in terms of religion, philosophy, politics and language

- beliefs, practices, traditions, customs and interpretations

- practical examples using real life scenarios (e.g., working with an interpreter; working with a client who cannot cook certain foods because of home/community influences

\section{DISCUSSION}

The successful interaction between cultures and the effective implementation of holistic care is dependent upon health care providers having a degree of cultural awareness and sensitivity to the needs of their migrant and refugee clients. Such 'competency' is theorized as facilitating and promoting the professional's ability to collaborate effectively with the client [14-16] and therefore to provide an effective service. It includes improving practitioner/patient communication and thereby, relationships, under- standing of diverse beliefs and perceptions about health and wellbeing [15]. From a social justice perspective, effective cultural health communication is equally important in ensuring fairness in healthcare access by CALD communities.

In addition, they contribute to blame allocation and labelling between health service providers and their clients. Hence, a client may be labelled as 'non-compliant' or 'difficult' for not following a professional's advice; a health service professional may be labelled as culturally incompetent or inappropriate in recommending food and lifestyle changes that are not feasible in faith-based and CALD environments or not practical for the every-day experiences of migrants and refugees as they adjust to the new country and its systems [17].

There has long been a call for healthcare providers to improve their level of knowledge about cultural differences and the different interpretations of health and illness by diverse communities [14, 18]. Effective health communication that is culturally suitable, and that is combined with diabetes prevention education, health promotion and management approaches that are tailored for migrant and refugee communities, is regarded as essential [19, 20]. Cultural diversity is said to be learnt through experience, education and training [21]. Providing training on diverse settings which cater to people from diverse cultures during the years of education to these health professionals would be beneficial and effective in attaining cultural competence. Provision of such training in diverse cultural settings during the years of training could put a good foundation to the future exposure to patients with diverse cultures by these health professionals.

Understanding or having a general idea of the culturally ascribed roles of men and women of different communities would be an important task for the health professional to facilitate optimal diabetes self-management and lifestyle change. Barriers to diabetes self-management included women not being allowed or licensed to drive, not being able to take public transport through fear or a cultural requirements, and not being given permission to talk or make eye contact with practitioners or interpreters during consultations. In some cultures, same sex practitioners were also a requirement. In others, there is a key person who cooks and shops - this person may not be the client. Such cultural differences suggested the need for practitioners to adopt a flexible approach and be sensitive to their ways and mannerisms. It requires the incorporation of searching for gender role and inclusion solutions in conjunction with the client, and/or 'researching' 
particular cultural considerations that might impact on the success of the service.

Furthermore, another major challenge that these health professionals faced was their interaction with the interpreters. Viewed collectively, interpreters seemed to be deemed as a 'necessary evil'. Accurate communication was identified as being clearly important for the treatment of clients with diabetes - treatment relying largely on client participation and self-management [22]. However, these client-centred interactions are difficult when there are considerable language barriers between patients and their health care professionals [22]. This was clearly seen as challenges for the interpreters by the health professional participants. For clients with diabetes, skilled interpretation is fundamental. It provides the foundations that underpin entry to, and effectiveness of, the treatment and advice provided by a practitioner. However, finding skilled interpretation is difficult as many are not trained to translate difficult health-related concepts (e.g., prevention of complications; self-management) and the words that are associated with diabetes (the word 'diabetes' itself), its pathophysiology and treatment, and the complications that may result if a client does not self-manage appropriately. These terms are difficult to 'translate' from one English speaker to another, and many are not easily shown or demonstrated with the use of current resources such as flyers in the client's language or generic posters [22]. Adding to the complexity of accurate translation, is the need to present in proper cultural contexts.

The results from this study and those from previous studies suggest that interpreter skills for diabetes care can be improved by focussed training on how to translate specific information that ensures diabetic clients with limited English, an understanding of how to care for themselves and, how to achieve optimal clinical outcomes [22].. Similarly, it is recommended that focus be placed on the understanding that many clients have language barriers that incorporate both verbal and written language; as well as illiteracy and innumeracy in some individuals in their own tongues [23-26]. Such illiteracy and innumeracy at very basic levels makes it difficult for some clients to read and understand prescriptions, their glucometers, nutritional percentages on food packaging, etc. Therefore, interpreter's training should also include how to manage such situations of clients in diabetes education. It is clear that there has to be a prior establishment of a professional relationship and a mutual understanding between the health professional and the interpreter/ translator. This would allow flexibility for both parties when treating the client. Temple and Edwards [27] stated the importance of the complexity of the task of the interpreter in the research process. It is mentioned that the interpretation of an interview involves a set of negotiations in relation to knowledge, language and identity. The involvement of interpreters in the health the care setting was argued and was concluded that the involvement of interpreters in analysing what the client says to the health professional should be taken into consideration if the gap between health professionals and interpreters/translators is to be resolved. For the interpreters' involvement in the analysis of the client's account and their diabetes management, it is important that a relationship needs to be established amongst the 2 professionals prior to their encounter with the client.

A number of project-specific challenges limit the interpretation of the results for policy and practice. Some aspects of this project had not been undertaken at the time of analysing these transcripts. These included the collection of materials used by practitioners and academics to work with, and teach about working with, migrants and refugees; and videos of actual consultations between practitioners and migrant/refugee clients.

\section{CONCLUSION}

What is surprising from this study relating to CALD is the very limited documentation or rather a gap in literature regarding diabetes prevalence, complications, health promotion and health practitioners within the CALD communities. There is a distinct lack of cultural education and understanding from health professionals, particularly within Australia and possibly worldwide. If we are to succeed in reducing the incidence of diabetes in the CALD background communities we first need to overcome the barrier created by the lack of cultural understanding of the culturally and linguistically diverse clientele of the health professionals. To achieve this it is important that health practitioners and students engage in an education or training programs to help address and overcome the issues that are confronted when dealing with CALD background communities. Only once this education issue has been resolved, major advances will result in the reduction of diabetes in the CALD communities.

\section{ACKNOWLEDGEMENTS}

The studies were undertaken at the former Australian Community Centre for Diabetes, Victoria University, Melbourne, Australia; Now Centre for Chronic Disease, Victoria University. The authors 
would like to thank Ms Kellie Fischer, Ms Betty Kafanelis and Prof Kerry Bennett for their invaluable assistance with the project.

\section{REFERENCES}

1. Vos T, Goss J, Begg S, Mann N: Australian Burden of Disease and Injury Study, Projected Health Care Costs Report, Australia. University of Queensland and the Australian Institute of Health and Welfare 2004:1-52.

2. FSANZ: Food Standards Australia and New Zealand. http://wwwfoodstandardsgovau/Pages/defaultaspx 2015.

3. Australia N: Nutritionist or Dietitian - which is for me? $\mathrm{http}: / /$ wwwnutritionaustraliaorg/national/nutritionist-or-dietitian-which-me 2016.

4. Govers E, Seidell JC, Visser M, Brouwer IA: Weight related health status of patients treated by dietitians in primary care practice: first results of a cohort study. BMC family practice 2014, 15:161.

5. Kousar R, Apostolopoulos V, Stojanovska L, Mayhew M, Totikidis V, Skaria A, Lewandowaski P: An Effective Model for Prevention and Management of Type 2 Diabetes. Qualitative health research 2015.

6. Lee JD, Saravanan P, Patel V: Alphabet Strategy for diabetes care: A multi-professional, evidence-based, outcome-directed approach to management. World journal of diabetes 2015, 6(6):874-879.

7. Denzin NK: Interpretative interactionism. Applied Society Research Method Series, 2nd Edition 2001, 16:1-170.

8. Apostolopoulos V, Borkoles E, Polman R, Stojanovska L: Physical and immunological aspects of exercise in chronic diseases. Immunotherapy 2014, 6(10):1145-1157.

9. Bosevski M, Stojanovska L, Apostolopoulos V: Inflammatory biomarkers: impact for diabetes and diabetic vascular disease. Acta biochimica et biophysica Sinica 2015, 47(12):10291031.

10. Stojanovska L, Apostolopoulos V, Polman R, Borkoles E: To exercise, or, not to exercise, during menopause and beyond. Maturitas 2014, 77(4):318-323.

11. WHO: Diabetes. http://wwwwhoint/mediacentre/factsheets/fs312/en/ 2016.
12. Joost HG: Pathogenesis, risk assessment and prevention of type $\mathbf{2}$ diabetes mellitus. Obesity facts 2008, 1(3):128-137.

13. Asian Health Support Service. The final report on healthcare needs of Asian people and health professionals in North and West Auckland, Auckland. Waitemata District Health Board 2001.

14. Anderson LM, Scrimshaw SC, Fullilove MT, Fielding JE, Normand J, Task Force on Community Preventive S: Culturally competent healthcare systems. A systematic review. American journal of preventive medicine 2003, 24(3 Suppl):68-79.

15. Calderon JL, Beltran RA: Culture and linguistics: neglected variables in the health communication equation. American journal of medical quality: the official journal of the American College of Medical Quality 2005, 20(4):179-181.

16. Manderson L, Allotey P: Story telling, marginality and community in Australia: How immigrants position their difference in health care settings. Medical Anthropology 2003, 22:1-21.

17. Borovoy A, Hines J: Managing the unmanageable: elderly Russian Jewish emigrés and the biomedical culture of diabetes care. Medical Anthropology Quarter 2008, 22:1-26.

18. Pearson A, Srivastava R, Craig D, Tucker D, Grinspun D, Bajnok I, Griffin P, Long L, Porritt K, Han T et al: Systematic review on embracing cultural diversity for developing and sustaining a healthy work environment in healthcare. International Journal of Evidence Based Healthcare 2008, 5:54-91.

19. Hawthorne K: Effect of culturally appropriate health education on glycaemic control and knowledge of diabetes in British Pakistani women with type 2 diabetes mellitus. Health education research 2001, 16(3):373-381.

20. Williams JH, Auslander WF, de Groot M, Robinson $\mathrm{AD}$, Houston $\mathrm{C}$, Haire-Joshu D: Cultural relevancy of a diabetes prevention nutrition program for African American women. Health promotion practice 2006, 7(1):56-67.

21. Bean R: The Effectiveness of Cross-Culture Training in the Australian Context. Canberra. Department of Immigration and Multicultural Affairs 2006.

22. McCabe M, Gohdes D, Morgan F, Eakin J, Schmitt C: Training effective interpreters for 
diabetes care and education: a new challenge. The Diabetes educator 2006, 32(5):714-720.

23. Colagiuri S, Colagiuri R: World J. National Diabetes Strategy and Implementation Plan. Canberra. Diabetes Australia 1998.

24. Dunstan DW, Zimmet PZ, Welborn TA, Cameron AJ, Shaw J, de Courten M, Jolley D, McCarty DJ, Australian Diabetes O, Lifestyle S: The Australian Diabetes, Obesity and Lifestyle Study (AusDiab)--methods and response rates. Diabetes research and clinical practice 2002, 57(2):119-129.

25. Dunstan DW, Zimmet PZ, Welborn TA, De Courten MP, Cameron AJ, Sicree RA, Dwyer
T, Colagiuri S, Jolley D, Knuiman M et al: The rising prevalence of diabetes and impaired glucose tolerance: the Australian Diabetes, Obesity and Lifestyle Study. Diabetes care 2002, 25(5):829-834.

26. Feldman R: Primary health care for refugees and asylum seekers: a review of the literature and a framework for services. Public health 2006, 120(9):809-816.

27. Temples B, Edwards R: Interpreters/translators in cross cultural research: reflexivity and border crossings. International Journal of Qualitative Methods 2002, 1:1-12.

\title{
Резиме
}

\section{ДИЈАБЕТЕС ТИП 2 КАЈ ЛУЃЕ СО РАЗЛИЧНО КУЛТУРНО И ЈАЗИЧНО ПОТЕКЛО: ПЕРСПЕКТИВИ ЗА ОБУКА И ПРАКТИКА ОД ПРОФЕСИОНАЛЦИ ЗА НУТРИЦИСКА ТЕРАПИЈА И ЗА ИСХРАНА}

\author{
Лили Стојановска ${ }^{1}$, Бенсри Немирач ${ }^{1,2}$, \\ Васо Апостолопулос ${ }^{1}$ \\ ${ }^{1}$ Центар за хронични болести, Школа за здравство и биомедицина, Мелбурн VIC 8001 Австралија \\ ${ }^{2}$ Тековна адреса, Градскиот совет Даребин, Gower Street, Престон, VIC, Австралија
}

\section{Апстракт}

Цел: Да се истражат перспективите на нутриционистите и на специјалистите за исхрана, студентите и професорите што работат со лица со дијабетес тип 2 , кои се од различно културно и јазично потекло.

Методи: Дизајн на квалитативна студија на детални полуструктурирани поединечни интервјуа со вкупно 24 учесници (8 лекари, 8 студенти и 8 професори) во областа на нутрициската терапија и диететиката. Отворените прашања беа фокусирани на перспективите и искуствата (учење, практика и настава) од работата со луѓе од различно културно и јазично потекло, кои имаат дијабетес тип 2. Сите интервјуа беа снимени за тематска и текстуална анализа.

Резултати: Меѓусебно поврзани теми, кои беа потврдени со истражувачка триангулација беа разбирање на: (i) концептите на култура и разновидност; (ii) концептите и влијанијата на здравјето, дијабетесот и храната во културите; (iii) влијанијата во и меѓу културите; и (iv) системи и ресурси. Перспективите во овие теми сугерираат фрустрација во однос на имањето доволен капацитет за целосна проценка, за изработка на ефективни, сеопфатни и високо квалитетни планови за управување и за постигнување на потребните здравствени промени во однесувањето на луѓето од различно културно и јазично потекло.

Заклучоци: Постои потреба за подобрување на додипломското образование и обука и во програмите за професионален развој; обуката и ресурсите на преведувачите во испораката на информации поврзани со здравјето и работата со здравствените работници; за фокус на културно соодветните планови за управување, кои вклучуваат консултации со клучните донесувачи на одлуки во семејствата и во заедниците; и, ревизија на системите за поддршка и ресурсите за нутрициски терапевти и диететичари во професионален развој од додипломски студии до ниво на практика.

Клучни зборови: служба за дијабетес, културна и јазична различност, различно културно и јазично потекло, диететичари, нутрициска терапија 